\title{
Carbon and nitrogen stocks in dead wood of tropical lowland forests as dependent on wood decay stages and land-use intensity
}

\author{
S. Meriem, S. Tjitrosoedirjo, M.M. Kotowska, D. Hertel, T. Triadiati
}

Meriem S., Tjitrosoedirjo S., Kotowska M.M., Hertel D., Triadiati T., 2016. Carbon and nitrogen stocks in dead wood of tropical lowland forests as dependent on wood decay stages and land-use intensity. Ann. For. Res. 59(2): 299-310.

Abstract. Rapid transformation of natural forests into other land-use systems in the lowlands of Sumatra, Indonesia, strongly reduces total aboveground biomass and affects nutrient cycling. However, the consequences of this conversion for $\mathrm{C}$ and $\mathrm{N}$ stocks of dead wood remains poorly understood particularly in natural forests and jungle rubber. This study examined the differences in dead wood abundance, mass, and $\mathrm{C}, \mathrm{N}$ and lignin concentrations of three decay stages of dead wood as well as the stocks of these chemical components stored in dead wood. Standing and fallen dead wood was determined as coarse woody debris with diameter $\geq 10 \mathrm{~cm}$ and classified into three decay stages of wood. Mass of dead wood was estimated using allometric equation. Total $\mathrm{C}$ and $\mathrm{N}$ stocks in dead wood in the natural forests (4.5 t C ha-1, $0.05 \mathrm{t} \mathrm{N} \mathrm{ha}^{-1}$, respectively) were three times higher than those in the jungle rubber $\left(1.5 \mathrm{t} \mathrm{C} \mathrm{ha}^{-1}, 0.02 \mathrm{t} \mathrm{N} \mathrm{ha}^{-1}\right.$, respectively). The stocks of $\mathrm{C}$ and $\mathrm{N}$ at early and advanced wood decay stages in the natural forests were also higher than those in the jungle rubber. The decay stages showed pronounced differences in concentrations of chemical components. With advancing stage of wood decay, $\mathrm{N}$ concentration increased and $\mathrm{C} / \mathrm{N}$ ratio decreased, while concentrations of $\mathrm{C}$ and lignin were variable. The distribution of dead wood mass and stocks of $\mathrm{C}$, and lignin were found to be higher in the early decay than those in the advanced decay stage. Higher input of dead wood in natural forests indicated a higher importance of dead wood decay in natural forests than in jungle rubber systems. Thus, replacing natural forests with jungle rubber strongly reduces total $\mathrm{C}$ and $\mathrm{N}$ stocks which might have a marked negative effect on the ecosystems' nutrient turnover and cycle.

Keywords dead wood mass, carbon and nitrogen stocks, decay stages, nutrient changes

Authors. Selis Meriem - Bogor Agricultural University, Kampus IPB Darmaga, Bogor 16680, Indonesia; Triadiati Triadiati (adiatiipb@gmail.com), Soekisman Tjitrosoedirjo - Department of Biology Faculty of Mathematic and Natural Sciences, Bogor Agricultural University, Dramaga Campus, Bogor, 16680, Indonesia; Martyna M. Kotowska, Dietrich Hertel - Albrecht von Haller Institute for Plant Sciences, Plant Ecology and Ecosystems Research, University of Goettin- 
gen, Untere Karspüle 2, 37073 Goettingen, Germany.

Manuscript received June 3, 2015; revised June 10, 2016; accepted June 20, 2016; online first July 28, 2016.

\section{Introduction}

Dead wood has been recognized to have an important ecological function as a resource for the ecosystem and structural components of forests (Harmon et al. 1986). A high abundance of dead wood on the forest floor maintains a high biodiversity of species such as saproxylic beetles (Floren et al. 2014) and fungi community which composition depends on the stage of decay of the dead wood (Kebli et al. 2012, Blaser et al. 2013). Enhancing dead wood amounts is expected to increase the habitat for forest biota. Dead wood also contributes a significant proportion to the total $\mathrm{C}$ stocks of aboveground wood mass (Pfeifer et al. 2015). This input serves as an important source to the nutrient flux to soil and consequentially affects the forest nutrient cycle. $\mathrm{C}$ sequestered in dead wood biomass effluxes through decomposition processes, thus dead wood plays a crucial role in global $\mathrm{C}$ cycling as well (Chambers et al. 2000). Dead wood not only stores $C$ retention as a fraction of total above-ground carbon pool, but also contributes to soil $\mathrm{C}$ sequestration (Pan et al. 2011).

Vegetation in forests without fertilizer inputs depends on available nutrients released from decomposition of dead organic matter including litter and woody debris. Dead wood not only composes active soil organic matter serving nutrient reservoirs for plant, but $\mathrm{C}$ and $\mathrm{N}$ stored in dead wood are also rapidly utilized by soil decomposer biomass as main energy source for growth demand and nutrient mineralization (Boddy \& Watkinson 1995, Lambers et al. 2008). Dead wood sequesters a large amount not only of $\mathrm{C}$ but also of nutrients, but decomposes at a lower rate than fine litter (Harmon \& Hua 1991) and has been reported to slowly release $\mathrm{N}$ to soil (Hafner \& Groffman 2005). Despite the low rate of decompo- sition, dead wood can be assumed to persist as $\mathrm{C}$ and $\mathrm{N}$ long-term storage form which makes it an important contribution to $\mathrm{C}$ and $\mathrm{N}$ cycles (Laiho \& Prescott 1999). The C stock source in dead wood is predominantly derived from lignin compounds (Austin \& Ballaré 2010). The lignin in dead wood consists of recalcitrant complex polymers considered as the inhibition factor for microorganism to decompose; thus causing the low decay rate and remaining long-term on the forest floor (Vanholme et al. 2010). Based on the crucial role of lignin in controlling $\mathrm{C}$ release, further studies on lignin stock in dead wood are highly required.

Given the importance of dead wood in nutrient cycling of forests, the storage and nutrient turnover are determined by substrate quality, decay stage, size, environmental factors such as moisture and temperature, and disturbance history (Harmon et al. 1986, Liu et al. 2013). Nutrient concentrations likely vary with decay stages as a result of decomposer activity, thus the amount of nutrients stored in dead wood may be altered during the decomposition process. Examining these concentrations in each decay stage will indirectly reflect on the dead wood nutrients which are transferred to the soil. Further, measuring $\mathrm{C}$ stocks of dead wood by utilizing $\mathrm{C}$ concentrations in each decay stages can avoid a biased estimation compared to using the $\mathrm{C}$ expansion factor (CEF). Since a high abundance of dead wood on the forest floor is expected to store large amounts of nutrients, neglecting to measure dead wood mass makes the estimate of nutrients returned to the soil remain unclear.

The ecological functions of dead wood have been studied extensively in temperate as well as in tropical forests (Aakala 2010, Palviainen et al. 2010, Yang et al. 2010). The mean stocks of dead wood $\mathrm{C}$ across tropical forests accounted for $17.5 \mathrm{t} \mathrm{C} \mathrm{ha}^{-1}$ (Pregitzer \& Eu- 
skirchen 2004). Dead wood contributes $16.6 \mathrm{t}$ $\mathrm{ha}^{-1}$ and $11 \%$ carbon stock of the world's forests (FAO 2010). In contrast to large C storages, there was a decrease of the $\mathrm{C}$ stocks of dead wood since 1990-2010 reported by FAO (2010) which was mainly driven by a reduced forest area. Deforestation of tropical forests in Indonesia occurs at a higher speed than natural forest cover loss in other tropical areas (Margono et al. 2014). Particularly lowland tropical rainforests in Jambi, Sumatra, have lost $78 \%$ of forest cover by land-use changes since 1985-2008 which turns them into critically endangered ecosystems (WWF 2010). Many native tree species in the natural forests of Jambi have been logged and replaced with rubber trees, since rubber latex is of high economic value for the communities (Gouyon et al. 1993). Natural forest transformed into other land-use forms is likely to change forest structure and its function. These changes probably alter dead wood contribution in the ecosystem. While recently most rubber land-use systems represent intensively managed monocultures, in earlier times natural rainforests have often been converted into rubber agroforestry systems containing a tree cover of natural tree species called 'jungle rubber'. Nevertheless, the effects of transformation of natural forest to jungle rubber on $\mathrm{C}$ and $\mathrm{N}$ stocks of dead wood are not investigated yet.

Based on the crucial role for estimating dead wood contribution, this study aims (1) to compare the total mass, stocks of $\mathrm{C}$ and $\mathrm{N}$ in dead wood between natural forest and jungle rubber, (2) to investigate the effect of decay stages on mass, volume, and nutrient stocks in dead wood mass, and (3) to assess the nutrient concentrations in each decay stage of wood. Our overarching goal is to obtain a basic and new idea of dead wood contribution to total $\mathrm{C}$ and $\mathrm{N}$ stocks in Indonesia tropical rainforests.

\section{Materials and methods}

\section{Study Site}

The research was conducted in natural forest and jungle rubber land-use systems in the tropical lowlands (51-95 $\mathrm{m}$ above sea level) of Jambi province, Sumatra. The climate is tropical humid (2374 $\mathrm{mm} \mathrm{yr}^{-1}$ ) with a mean annual air temperature of $26.9^{\circ} \mathrm{C}$ and mean relative humidity of $86 \%$ (climate data from Jambi climate station (Stasiun Klimatologi Jambi: N $1^{\circ} 62.1^{\prime}$, E $\left.103^{\circ} 53.1^{\prime}\right)$. Study sites were located in two landscapes: Harapan (Muara Bulian regency) and Bukit Duabelas National Park (TNBD) (Sarolangun regency) within Jambi province. We investigated four plots of natural forest and four plots of jungle rubber in each region resulting eight plots (replications) for each land-use systems. The natural forest was degraded primary forest with selective logging in the past. The jungle rubber system was a rubber agroforest with natural tree cover where forest trees were logged and rubber trees planted in the gaps between 1973 and 2006. Canopy cover and total basal area in the natural forest were $92.1 \pm 0.5 \%$ and $30.1 \pm 0.9 \mathrm{~m}^{2} \mathrm{ha}^{-1}$, respectively, whereas in the jungle rubber the numbers were $87.6 \pm 0.8 \%$ and $18.3 \pm 1.1 \mathrm{~m}^{2}$ ha $^{-1}$, respectively (Kotowska et al. 2015).

\section{Dead wood Inventory}

The sampling method was carried out in a non-destructive way. Dead wood i.e. standing and fallen dead wood pieces were monitored within permanent plots of $2500 \mathrm{~m}^{2}(50 \mathrm{~m}$ x 50 $\mathrm{m})$ in a total of sixteen plots (eight replicates per land-use system). The size standing dead wood $(\mathrm{dbh} \geq 10 \mathrm{~cm}$, height $\geq 1.5 \mathrm{~m})$ and fallen dead wood (diameters $\geq 10 \mathrm{~cm}$ at the midpoint, length $\geq 1 \mathrm{~m}$ ) were measured. Dead wood diameter was measured using a dendrometer tape (UMS, Munchen, Germany), height of standing dead wood measured using a Vertex III height meter (Haglof, Langsele, Sweden), 
and length of fallen dead wood measured using a meter tape. Wood density $(\rho)$ was measured using Pilodyn 6J wood tester (PROCEQ SA, Zürich, Switzerland). The penetration depth (h) of the pin was converted using a calibration equation derived by Kotowska et al. (2015) (Eq. 1), based on 204 trees which wood core samples were analyzed.

$\ln (p)=0.8711-0.5763 \ln (h)$

Decay wood was qualitatively identified based on physical indicators according to Grove (2001) and classified into one of three stages (Table 1).

\section{Estimation of dead wood mass}

Allometric equations were used to estimate the mass of dead wood. Mass of decay stage I and II were estimated using the equation for AGB (aboveground biomass) by Chave et al. (2005) (Eq. 2). The proportion of missing components was subtracted from the outcome (Kauffman \& Donato 2012). The mass of decay stage I was subtracted by $2.5 \%$ of leaf mass estimate (Eq. 3 ). The mass of decay stage II was subtracted by $15 \%$ of lost branches and twigs (Eq. 4 ). The mass measurement for decay stage III used the cylinder volume and multiplied by wood density (Eq. 5) (Hairiah et al. 2011). The value of the mass measurements $(\mathrm{kg})$ were converted in tonnes per hectare. The parameters which were used in the formula were wood density $(\rho, g$ $\left.\mathrm{cm}^{-3}\right)$, diameter $(\mathrm{d}, \mathrm{cm})$ and height or length $(\mathrm{h}$, $\mathrm{m})$.

$A G B=0.0509 \times \rho \times d^{2 \times} h$
Decay stage $1=A G B-25 \%$

Decay stage $2=A G B-15 \%$

Decay stage $3=\left(\rho^{\times} \pi^{\times} d^{2} \times h\right) / 40$

\section{Analyses of organic carbon, total nitrogen and lignin}

In total, 261 pieces of dead wood were extracted and cut into smaller pieces; cleaned from roots, soil, mosses, fungi, and insects; samples were then dried at $80^{\circ} \mathrm{C}$ to a constant weight then ground. For each decay stage, 48 representative samples were selected randomly to analyse their chemical properties.

Organic C was measured using Walkley and Black method following boiled of $0.1 \mathrm{~g}$ (dried weight) sampel at $90^{\circ} \mathrm{C}$ for $2 \mathrm{~h}$ in $10 \mathrm{ml}$ of $\mathrm{K}_{2} \mathrm{Cr}_{2} \mathrm{O}_{7} 2 \mathrm{~N}$ and $7.5 \mathrm{ml}$ of $\mathrm{H}_{2} \mathrm{SO}_{4}$ p.a., diluted with $100 \mathrm{ml}$ aquadest, pipetted $10 \mathrm{ml}$ and added with 3 drops of ferroin, and titrated with $0.2 \mathrm{~N} \mathrm{FeSO}_{4}$. Total $\mathrm{N}$ was measured using the Kjeldahl method following destruction of 0.1 $\mathrm{g}$ sample by heated at $340^{\circ} \mathrm{C}$ for $45 \mathrm{~m}$ in $5 \mathrm{ml}$ $\mathrm{H}_{2} \mathrm{SO}_{4}$ and 0.2 selenium then diluted with 50 $\mathrm{ml}$ aquadest, destilation with $\mathrm{NaOH} 40 \%$ for $3 \frac{1}{2} \mathrm{~m}$ and fixation of vapour $\mathrm{NH}_{3}$ in solution of 3 drops conway and $10 \mathrm{ml}$ boric acid, and titration with $0.02 \mathrm{~N} \mathrm{HCl}$. The $\mathrm{C} / \mathrm{N}$ ratio was determined by dividing total $\mathrm{C}$ by total N. Lignin content was measured using Van Soet method after analyzed ADF (Acid Detergent Fiber) content which represented undissolved cell wall compartment in CTAB solution (Cetyl Trimethyl Ammonium Bromide). One g sample was extracted for $1 \mathrm{~h}$ in $100 \mathrm{ml}$ ADS solution (Acid Detergent Solution) which made by dissolved $20 \mathrm{~g}$ CTAB and $27.5 \mathrm{ml} \mathrm{H}_{2} \mathrm{SO}_{4} 1 \mathrm{~N}$

Table 1 Classification of dead wood decay stages

\begin{tabular}{ll}
\hline Decay stages of wood & Indicators \\
\hline I (early decay) & $\begin{array}{l}\text { Intact bark, loss of leaves, retaining wood integrity } \\
\text { II (intermediate decay) }\end{array}$ \\
$\begin{array}{l}\text { Less intact bark, slight rot wood structure but still supporting mechanically, } \\
\text { partially invaded root }\end{array}$ \\
III (advanced decay) & $\begin{array}{l}\text { Loose bark, no longer retains original shape, largely disintegrated, spreading } \\
\text { invaded root }\end{array}$ \\
\hline
\end{tabular}


in $1 \mathrm{~L}$ aquadest, filtrated through sintered glass plate, rinsed residue with hot water and acetone, and dried at $105^{\circ} \mathrm{C}$ for $\pm 4 \mathrm{~h}$. The residue was burned at $\pm 600^{\circ} \mathrm{C}$ for lignin content.

Stocks of $\mathrm{C}, \mathrm{N}$, and lignin were calculated by multiplying the mass $\left(\mathrm{t} \mathrm{ha}^{-1}\right)$ of each compartment by its respective mean chemical concentration (\%) for each decay stage. Volume of dead wood was measured by dividing wood mass with its density.

\section{Statistical analyses}

In this study, two plots (one jungle rubber and one forest plot) were excluded from further analysis due to their discrepancy of vegetation and structural characteristics; thus value of those plots have been transformed by approaching the mean value from the similar region in similar system. In the excluded jungle rubber plot, large dead wood amounts of slowly decomposing hardwood remained after recent conversion from natural forest. The excluded forest plot showed a small number and biomass of dead wood which indicated distinct differences compared to all other forest sites. In case, data analyses were tested using square root transformation value of $\sqrt{ }(x+1)$.

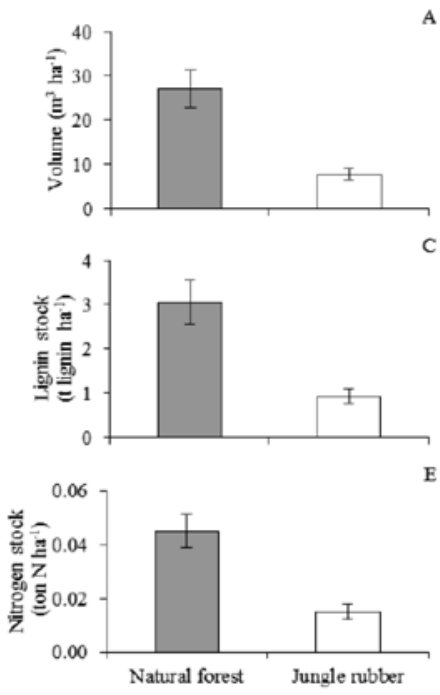

The effect of land-use system on parameters (mass, volume and stocks of $\mathrm{C}, \mathrm{N}, \mathrm{C} / \mathrm{N}$ ratio and lignin in dead wood), as well as in each decay stage, were compared using Independent Sample t-test. Analyses of variance (ANOVA), One-Way with post-hoc Tukey HSD test were used to determine the influence of decay stages on these parameters and on the nutrient concentrations of $\mathrm{C}, \mathrm{N}, \mathrm{C} / \mathrm{N}$ ratio and lignin. All analyses were conducted using SPSS version 19 with statistical significance established at $\alpha=5 \%$ level. A principal component analyses (PCA) of chemical, anatomical dead wood properties and chemical stand stocks in of the three different decay stages in the two different land-use systems was conducted with the package CANOCO, version 4.5 (Biometris, Wageningen, The Netherlands).

\section{Results}

Total dead wood volume and mass in natural forest were significantly higher than those in jungle rubber $(\mathrm{p}<0.05)$ (Fig. 1A and $1 \mathrm{~B})$. The higher mass of dead wood in the natural forest subsequently led to a highly significant differences in stocks of lignin, $\mathrm{C}$, and $\mathrm{N}$ compared to

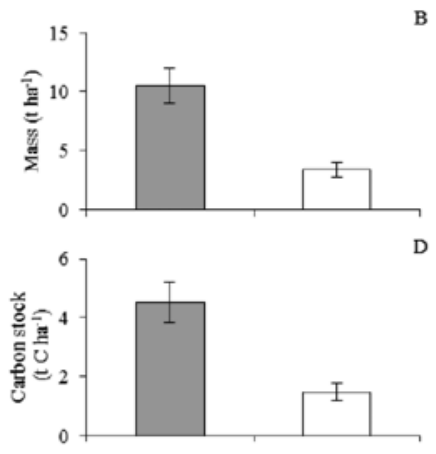

\section{Figure 1}

Total volume (A), mass (B), lignin stock (C), carbon stock (D), and nitrogen stock (E) of dead wood on land-use systems. Bars represent mean \pm SE. 
the jungle rubber $(\mathrm{p}<0.05)$ (Fig. 1 C-E).

Each decay stage of dead wood had different volume, mass, and stocks of lignin, $\mathrm{C}$, and $\mathrm{N}$ that differed as well as between natural forest and jungle rubber (Table 2). These parameters were significantly higher for decay stage I in the natural forest compared to the jungle rubber $(p<0.05)$ as well as for decay stage III $(p<$ 0.05 ), while there was no significant difference between the two systems for decay stage II ( $\mathrm{p}$ $>0.05$ ) (Table 2).

There were no significant effects of dead wood decay stages on lignin and $\mathrm{C}$ concentrations ( $p>0.05)$ (Fig. 2A and 2B). While there were strong significant influences of the decay stages on $\mathrm{N}$ concentration and $\mathrm{C} / \mathrm{N}$ ratio in dead wood $(\mathrm{p}<0.05)$. Figure $2 \mathrm{C}$ shows that the $\mathrm{N}$ concentration in decay stage III was significantly highest among the decay stages $(\mathrm{p}<$ 0.05 ), whereas the $\mathrm{C} / \mathrm{N}$ ratio in the decay stage III was significantly lowest among the decay stages ( $\mathrm{p}<0.05)$ (Fig. 2D).

Nutrient stocks of dead wood in each decay stage represented the value from both systems. Dead wood mass and stocks of were significantly influenced by the decay stage of wood $(p<0.05)$, while no significant effects were found in volume of dead wood and N stock ( $\mathrm{p}$ $>0.05$ ) (Fig. 3 A-E). The mass and stocks of lignin and $\mathrm{C}$ of dead wood were significantly higher in the decay stage I than the decay stage III (Fig. 3B and 3D). These variables decreased with advancing wood decay stages.

The results from the principal component analysis show that the natural forest and the jungle rubber plots are clearly separated from each other (Fig. 4). Axis \#1 with the highest explanatory value (EV 0.56) is closest associated with the proportional dead wood $\mathrm{C}$ in total aboveground $\mathrm{C}$ stock as well as with the chemical dead wood properties (but not lignin content), and live stem wood density (Fig. 4, Table 3). Therefore, dead wood $\mathrm{C}$ and $\mathrm{N}$ content, and $\mathrm{C} / \mathrm{N}$ ratio as well as live wood density are the crucial factors separating the three dead wood decay stages in jungle rubber plots, but not in natural forest plots (Fig. 4). C, N and lignin stocks are partly associated with axis \#1 as well, but were even more strongly correlated with axis \#2. Lignin content was closest associated with the axis \#3 and was explanatory for the separation of the three decay stages in the natural forest plots.

Table 2 Volume, mass, stocks of lignin, C, and $\mathrm{N}$ values of dead wood on decay stage in natural forest and jungle rubber. No significance in decay stage II between two land-use systems.

\begin{tabular}{|c|c|c|c|}
\hline Variables & $\begin{array}{l}\text { Decay stages } \\
\text { of wood }\end{array}$ & Natural forest & Jungle rubber \\
\hline \multirow[t]{3}{*}{ Volume $\left(\mathrm{m}^{3} \mathrm{ha}^{-1}\right)$} & I & $10.15(1.31)^{*}$ & $2.38(0.66)^{*}$ \\
\hline & II & $7.40(2.79)^{\mathrm{n} . \mathrm{s}}$ & $3.25(0.62)^{\mathrm{n} . \mathrm{s}}$ \\
\hline & III & $9.48(2.72)^{*}$ & $2.17(0.54)^{*}$ \\
\hline \multirow[t]{3}{*}{$\operatorname{Mass}\left(\mathrm{t} \mathrm{ha}^{-1}\right)$} & I & $4.87(0.71)^{*}$ & $1.49(0.41)^{*}$ \\
\hline & II & $2.93(0.95)^{n . s}$ & $1.27(0.29)^{\mathrm{n.s}}$ \\
\hline & III & $2.71(0.78)^{*}$ & $0.62(0.15)^{*}$ \\
\hline \multirow[t]{3}{*}{ Lignin stock $\left(\mathrm{t}\right.$ lignin $\left.\mathrm{ha}^{-1}\right)$} & I & $1.45(0.23)^{*}$ & $0.45(0.11)^{*}$ \\
\hline & II & $0.76(0.25)^{\mathrm{n} . \mathrm{s}}$ & $0.32(0.05)^{\mathrm{n} . \mathrm{s}}$ \\
\hline & III & $0.85(0.23)^{*}$ & $0.18(0.05)^{*}$ \\
\hline \multirow[t]{3}{*}{ Carbon stock ( $\left.\mathrm{t} \mathrm{C} \mathrm{ha}^{-1}\right)$} & I & $2.07(0.32)^{*}$ & $0.67(0.18)^{*}$ \\
\hline & II & $1.31(0.43)^{\mathrm{n} . \mathrm{s}}$ & $0.55(0.13)^{\mathrm{n} . \mathrm{s}}$ \\
\hline & III & $1.15(0.33)^{*}$ & $0.26(0.07)^{*}$ \\
\hline \multirow[t]{3}{*}{ Nitrogen stock $\left(\mathrm{t} \mathrm{N} \mathrm{ha}^{-1}\right)$} & I & $0.019(0.003)^{*}$ & $0.005(0.001)^{*}$ \\
\hline & II & $0.012(0.004)^{\mathrm{n} . \mathrm{s}}$ & $0.005(0.001)^{\text {n.s }}$ \\
\hline & III & $0.015(0.004)^{*}$ & $0.004(0.001)^{*}$ \\
\hline
\end{tabular}

Note. Abbreviation: ${ }^{*} p<0.05$. n.s - not significant. Values show mean (SE). 

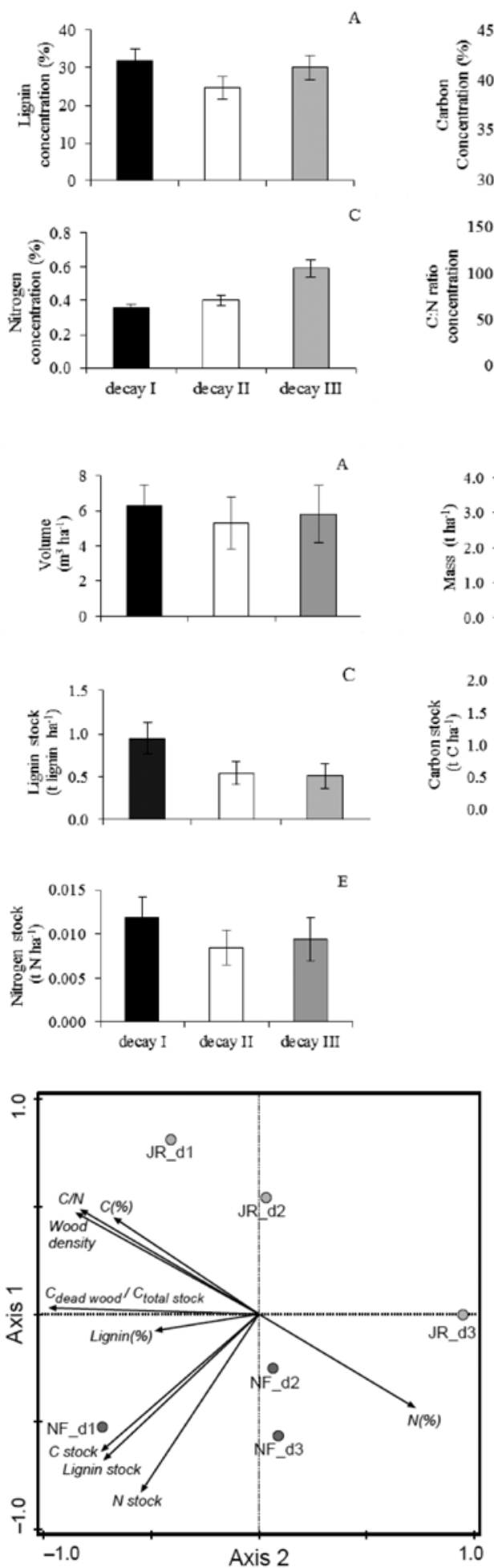

\section{B Figure 2}

Concentrations of lignin (A), carbon (B), nitrogen (C), and C:N ratio (D) values in wood decay stage of dead wood. Bars represent D mean \pm SE. No significance in lignin and $\mathrm{C}$ concentration values.

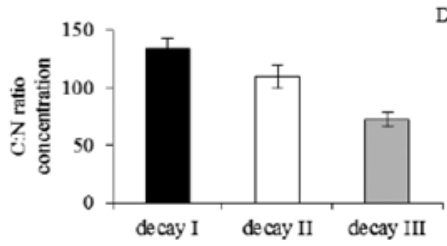

B
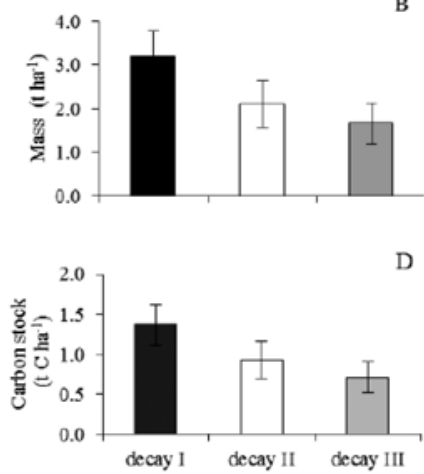

\section{Figure 3}

Volume (A), mass (B), lignin stock $(\mathrm{C})$, carbon stock (D), and nitrogen stock (E) values in wood decay stages of dead wood. Bars represent mean \pm SE. No significance in volume and nitrogen stock values.

\section{Figure 4}

Principal component analysis (PCA) of carbon, nitrogen, and lignin concentration as well as the $\mathrm{C}, \mathrm{N}$, and lignin stocks, and the ratio of $\mathrm{C}$ stock in dead wood to total (live and dead above-ground $\mathrm{C}$ stock) of the three decay stages in the two land-use systems. 'NF' refers to the natural forest plots, 'JR' refers to the Joungle rubber plots. 'd1', 'd2','d3' specifies the three different dead wood decay stages. 


\section{Discussion}

Conversion of natural forest to jungle rubber reduced the total volume and mass (Fig. $1 \mathrm{~A}-\mathrm{B}$ ), as well as stocks of lignin, $\mathrm{C}$, and $\mathrm{N}$ of dead wood (Fig. $1 \mathrm{C}-\mathrm{E}$ ). The natural forest stored three times more $\mathrm{C}$ and $\mathrm{N}$ stocks of dead wood than the jungle rubber. These differences may be associated with the living stand productivity from which dead wood origins. In the natural forest total aboveground tree biomass (AGB) was more than two times higher and aboveground net primary productivity (NP$\mathrm{P}_{\text {wood }}$ ) was also higher than in the jungle rubber systems (Kotowska et al. 2015). The high AGB and $\mathrm{NPP}_{\text {wood }}$ in the natural forest could have one reason for the higher dead wood mass, bearing on its capacity to store stocks of $\mathrm{C}$ and $\mathrm{N}$. The larger mean diameter and height of living trees in the aboveground structure of the natural forest provided evidence for a higher dead wood biomass (Kotowska et al. 2015). As a result, jungle rubber systems apparently lack large dead wood pieces which is more of a structural characteristic of natural forests.

The differences in dead wood volume and mass, as well as in lignin, $\mathrm{C}$, and $\mathrm{N}$ stocks in dead wood between natural forest and jungle rubber systems varied among decay stages of wood (Table 2). High stocks of $\mathrm{C}$ and $\mathrm{N}$ in the natural forest, i.e. in the early and advanced stages of wood decay, were also caused by high stand productivity and probably derived also from past logging residues remained in the forest. In general, the effect of disturbance history determines the amount of dead wood in an ecosystem (Gurdak et al. 2013, Pfeifer et al. 2015). As almost all primary forests were at least logged over in the Jambi province (Gouyon et al. 1993), it is difficult to disentangle the effects of natural processes from human disturbance effects. In the intermediate decay stage, large residues of recent logging could be the possible cause of dead wood accumulation in the jungle rubber, therefore accounting for similar results in both systems. In the jungle rubber system human influence is much more pronounced, therefore tree mortality might increasingly occur due to the anthropogenic damage or tree logging. The abundance of fast-growing species such as Macaranga spec. in the jungle rubber system may also cause a high input source of dead wood (Rembolt et al. unpublished data). Despite this, the dead wood stocks of $\mathrm{C}$ and $\mathrm{N}$ were still higher in the natural forest.

Dead wood in the natural forest retained long-term $\mathrm{C}$ as well as $\mathrm{N}$ storage (Olajuyigbe et al. 2011), these stocks provide a large potential for chemical element transfer to the soil. We assumed that high lignin stocks in the natural forest served as the $\mathrm{C}$ stock source are expected to retain a long-term storage in this system supporting the longevity of dead wood on the forest floor. A dense canopy cover and high basal area in the natural forest are clear reasons for lower air temperature and higher air humidity than in the jungle rubber system (Kotowska et al. 2015). These microclimate properties in the natural forest plots represent favourable conditions for microorganism degrading dead wood (Zhou et al. 2007). Conversion of natural forest into jungle rubber systems may not only impact the microclimate conditions, but may likely alter also other environmental factors such as soil organic matter composition, which therefore alter the microbial and fungal community as well which in turn will influence the dead wood degradation. These findings are strongly supported by Guillaume et al. (2015) who reported loss of soil organic $\mathrm{C}$ and soil organic $\mathrm{N}$ in the top soil of jungle rubber at the same study sites. The reduced soil organic matters give evidence that decreased stocks of dead wood in the jungle rubber may be one of the factors leading to reduced $\mathrm{C}$ and $\mathrm{N}$ input to the soil. Therefore, high stocks of $\mathrm{C}$ and $\mathrm{N}$ from dead wood in the natural forest indirectly indicate a better soil fertility.

Dead wood mass in our study accounted for $2.7 \%$ and $2.3 \%$ of total AGB in natural forest and in jungle rubber, respectively. Comparing with similar studies from other tropical rain- 
forests, this current finding was lower than in Peru in which dead wood accounted for 7.59.3\% of total AGB (Baker et al. 2007). Pregitzer \& Euskirchen (2004) reported that the mean $\mathrm{C}$ pool of woody debris across tropical forests amounted to $10 \%$ of the total carbon stocks. Dead wood contributed $2.3 \%$ of total aboveground $\mathrm{C}$ stocks in the natural forest and $1.9 \%$ of that in the jungle rubber (Kotowska et al. 2015). These values were five times lower compared to $33 \%$ of the $\mathrm{C}$ stock in Costa $\mathrm{Ri}$ can natural forests (Clark et al. 2002).

Regarding the importance of dead wood in the nutrient cycle of forest ecosystems it is not only important to assess nutrient concentrations and stocks in dead wood, but to consider that nutrient release from degraded dead wood in each decay stage of dead wood is indirectly linked to microbial activities during the decay that allow the breakdown of organic compounds. In accordance with previous findings by Lombardi et al. (2013) and Strukelj et al. (2013), N concentration increased and $\mathrm{C} / \mathrm{N}$ ratio decreased with the advancing stage of wood decay in our study (Fig. 2C and 2D). Substrate quality and microbial activity probably enhanced $\mathrm{N}$ concentration in advanced decaying dead wood through (1) $\mathrm{N}$ translocation from immobilized soil nutrient mediated by microorganisms i.e., fungi (Philpott et al. 2014), (2) increased activity of asymbiotic N-fixing bacteria (Brunner \& Kimmins 2003) and (3) increased $\mathrm{N}$ structural binding with lignin, aromatic and phenolic compounds which were resistant to be degraded (Hishinuma et al. 2015). In our study, neither lignin nor $\mathrm{C}$ concentrations differed maredly among wood decay stages (Fig. 2A and 2B), as also found by Harmon et al. (2013). Lignin has a complex structure of phenylpropanoid polymers that is rich in $\mathrm{C}-\mathrm{C}$ bond and ether. Therefore, $\mathrm{C}$ is the largest constituent of lignin (63-72\%) (Harmon et al. 2013). During decaying processes, soluble $\mathrm{C}$ in active organic $\mathrm{C}$ of dead wood is consumed for microorganism demand (Anderson \& Dousch 1989), while passive C fraction is slowly decomposing because of its accumulation in persistent organic matter of lignin (Bonanomi et al. 2013). Similar to finding of Hishinuma et al. (2015), increased lignin-C content and decreased polysaccharide- $\mathrm{C}$ were found in advanced decay of wood in this study. The abundance of dead wood mass and stocks of lignin, $\mathrm{C}$, and $\mathrm{N}$ were dominated by early decayed wood which might reflect a low decay process intensity of the woody debris in our plots. The influence of wood decay stages to these parameters might be affected by factors of wood mass and changes of its respective chemical concentrations. High mass in early decay stage led to high stocks of lignin and C, but not $\mathrm{N}$ stock (Fig. 3 B-E). These were primarily related to the high dead wood mass toward high mean concentration of lignin and C. As well as in advanced decay stage, low mass of dead caused low stocks of lignin and C. The variability of $\mathrm{N}$ stocks among decay stages was mostly due to the high dead wood mass with low $\mathrm{N}$ concentration in the early decay of wood and in contrast to advanced stage, as also found by Guo et al. (2014). Diameter and length of dead wood were variable among decay stages, and thus influencing the volume value (Fig. 3A). Given that wood density determined the decay advances, mass estimated by measuring wood density more appropriately reflected the stage of wood decay than volume. Large amounts of nutrient retained on the forest floor in early decay stage are expected to contribute as a nutrient source for regenerating trees and decomposer biomass. Low dead wood abundance in advanced decay stage might be due to the losses of its mass and nutrients caused by degrading process by decomposers. Essentially, this indicates that nutrient stocks in dead wood are transferred to the environment.

Vegetation composition, stand productivity, substrate quality, canopy closure and microclimate were altered in jungle rubber referred as converted natural forests, as well as systems were separated in PCA results (Fig. 4 and Ta- 
ble 3). Low mass of small dead wood diameter in jungle rubber cause soil decomposers rapidly colonize wood compartment (Harmon et al. 1986). When nutrient released faster by decomposers, the substrate quality of $\mathrm{C}, \mathrm{N}$ and $\mathrm{C} / \mathrm{N}$ ratio, and live wood density were primarily factors to distinguish wood decay stages. The $\mathrm{C}$ is effluxed by decomposer respiration as decay proceeds and $\mathrm{N}$ is immobilized into mass of dead wood and retained as structural resistance hence $\mathrm{C} / \mathrm{N}$ ratio is decreased as well as wood density (Rajala et al. 2012). In natural forests, high stand productivity and lignin concentrations contributed to high dead wood stocks of lignin, C and N . Decomposers slowly degrade wood fractions spreading throughout large piece of dead wood (Mackensen \& Bauhus 2003), while lignin concentrations is a resistant factor for decomposer activities. Thus, stored nutrient in mass and lignin of dead wood were strongly main factors in separating wood decay in natural forests.

\section{Conclusion}

The findings of this study showed that (1) total mass, $\mathrm{C}$ and $\mathrm{N}$ stocks of dead wood in natural forest were higher than those in jungle rubber, as well as found in the early and advanced wood decay stages. Transformation of natural forest into jungle rubber resulted in losses of $\mathrm{C}$ and $\mathrm{N}$ stocks, thus reduced dead wood contribution which is regarded as an important component of the ecosystem, (2) N concentrations were found to increase with advancing wood decay contrary to the $\mathrm{C} / \mathrm{N}$ ratio, while $\mathrm{C}$ and lignin concentrations remained variable among decay stages of wood, and (3) the abundance of biomass and stocks of $\mathrm{C}$ and lignin of dead wood were higher in the early stage than the advanced stage of wood decay. Consequently, the current study implies that converting natural forest to jungle rubber systems not only reduces total mass of dead wood, but also decreases $\mathrm{C}$ and $\mathrm{N}$ stocks both in total and in the different stages of wood decay. As a consequence, this will affect long-term sustainability of soil nutrients. Nutrient stocks in jungle rubber will be decreased in the future and this reduction will continue to increase if remaining forest vegetation is replaced with young rubber stands. We suggest allowing a proportion of dead wood amount to decay by natural process as an indirect approach to maintain soil fertility.

\section{Acknowledgements}

This study was financed by the Deutsche Forschungsgemeinschaft (DFG) in the framework of the collaborative German - Indonesian research project CRC990 and Directorate General of Higher Education (DIKTI) on Interior Graduate Education Scholarship (BPPDN) Candidate Lecturer 2013. We thank village leaders, local plot owners, PT REKI, Bukit Duabelas National Park as well as counterparts.

\section{References}

Aakala T., 2010. Coarse woody debris in late-successional Picea abies forests in northern Europe: Variability in quantities and models of decay class dynamics. Forest Ecology and Management 260:770-779. DOI: 10.1016/j.foreco.2010.05.035.

Anderson T., Dousch K.H., 1989. Ratios of microbial biomass carbon to total organic carbon in arable soils. Soil Biology and Biochemistry 21: 471-479. DOI: 10.1016/0038-0717(89)90117-X.

Austin A.T., Ballaré C.L., 2010. Dual role of lignin in plant litter decomposition in terrestrial ecosystems. Enviromental Sciences 107: 2-6. DOI: 10.1073/ pnas.0909396107.

Baker T.R., Honorio Coronado E.N., Phillips O.L., Martin J, van der Heijden G.M.F, Garcia M., Silva Espejo J., 2007. Low stocks of coarse woody debris in a southwest Amazonian forest. Oecologia 152: 495-504. DOI: 10.1007/s00442-007-0667-5.

Blaser S., Prati D., Senn-Irlet B., Fischer M., 2013. Effects of forest management on the diversity of deadwood-inhabiting fungi in Central European forests. Forest Ecology and Management 304: 42-48. DOI: 10.1016/j.foreco.2013.04.043.

Boddy L., Watkinson S.C., 1995. Wood decomposition, 
higher fungi, and their role in nutrient redistribution. Canadian Journal of Botany 73: 1377-1383. DOI: $10.1139 / \mathrm{b} 95-400$.

Bonanomi G., Incerti G., Giannino F., Mingo A., Lanzotti V., Mazzoleni S., 2013. Litter quality assessed by solid state ${ }^{13} \mathrm{C}$ NMR spectroscopy predicts decay rate better than $\mathrm{C} / \mathrm{N}$ and Lignin/ $\mathrm{N}$ ratios. Soil Biology and Biochemistry 56: 40- 48. DOI: 10.1016/j.soilbio.2012.03.003.

Brunner A, Kimmins J.P., 2003. Nitrogen fixation in coarse woody debris of Thuja plicata and Tsuga heterophylla forests on northern Vancouver Island. Canadian Journal of Forest Research 33: 1670-1682. DOI: 10.1139/X03-085.

Chambers J.Q., Higuchi N., Schimel J.P., Ferreira L.V., Melack J.M., 2000. Decomposition and carbon cycling of dead trees in tropical forests of the central Amazon. Oecologia 122: 380-388. DOI: 10.1007/ s004420050044.

Chave J., Andalo C., Brown S., Cairns M.A., Chambers J.Q., Eamus D., Folster H., Fromard F., Higuchi N., Kira T., Lescure J.P., Nelson B.W., Ogawa H., Puig H., Riera H., Yamakura T., 2005. Tree allometry and improved estimation of carbon stocks and balance in tropical forest. Oecologia 145: 87- 99. DOI 10.1007/ s00442-005-0100-x.

Clark D.B., Clark D.A., Brown S., Oberbauer S.F., Veldkamp E., 2002. Stocks and flows of coarse woody debris across a tropical rain forest nutrient and topography gradient. Forest Ecology and Management 164: 237248. DOI: 10.1016/S0378-1127(01)00597-7.

FAO, 2010. Global forest resources assessment. In: FAO Forestry Paper No. 163. Food and Agriculture Organization of the United Nations, Rome, $340 \mathrm{p}$.

Floren A., Müller T., Dittrich M., Weiss M., Linsenmair K.E., 2014. The influence of tree species, stratum and forest management on beetle assemblages responding to deadwood enrichment. Forest Ecology and Management 323: 57-64. DOI: 10.1016/j.foreco.2014.03.028.

Gouyon A., Deforesta H., Levang P., 1993. Does 'jungle rubber' deserve its name? An analysis of rubber agroforestry systems in southeast Sumatra. Agroforestry Systems 22: 181-206. DOI: 10.1007/BF00705233.

Grove S.J., 2001. Extent and composition of dead wood in Australian lowland tropical rainforest with different management histories. Forest Ecology and Management 154: 35-53. DOI: 10.1016/S0378-1127(00)006186.

Guillaume T., Damris M., Kuzyakov Y., 2015. Losses of soil carbon by converting tropical forest to plantations: erosion and decomposition estimated by $\delta^{13} \mathrm{C}$. Global Change Biology 21: 3548-3560. DOI: 10.1111/ gcb. 12907.

Guo J., Chen G., Xie J., 2014. Patterns of mass, carbon and nitrogen in coarse woody debris in five natural forests in southern China. Annals of Forest Science 71: 585-594. DOI 10.1007/s13595-014-0366-4.

Gurdak D.J., Aragão L.E.O.C., Rozas-Dávila A., Huasco
W.H., Cabrera K.G., Doughty C.E., Farfan-Rios W., Silva-Espejo J.E., Metcalfe D.B., Silman M.R., Malhi Y., 2013. Assessing above-ground woody debris dynamics along a gradient of elevation in Amazonian cloud forests in Peru: balancing above-ground inputs and respiration outputs. Plant Ecology \& Diversity 7: 143-160. DOI: 10.1080/17550874.2013.818073.

Hafner S.D., Groffman P.M., 2005. Soil nitrogen cycling under litter and coarse woody debris in a mixed forest in New York State. Soil Biology and Biochemistry 37: 2159-2162. DOI: 10.1016/j.soilbio.2005.03.006.

Hairiah K., Ekadinata A., Sari R.R., Rahayu S., 2011. Pengukuran cadangan carbon dari tingkat lahan ke bentang lahan. $2^{\text {th }}$ Ed. World Agroforestry Centre, Bogor, ID, pp. 35.

Harmon M.E., Fasth B., Woodall C.W., Sexton J., 2013. Carbon concentration of standing and downed woody detritus: Effects of tree taxa, decay class, position, and tissue type. Forest Ecology and Management 291: 259267. DOI: 10.1016/j.foreco.2012.11.046.

Harmon M.E., Franklin J., Swanson F., Sollins P., Gregory S., Lattin J., Anderson N., Cline S., Aumen N., Sedell J., Lienkaemper G.W., Cromack K., Cummins K.W., 1986. Ecology of coarse woody debris in temperate ecosystems. Advances in Ecological Research 15: 133302. DOI: 10.1016/S0065-2504(08)60121-X.

Harmon M.E., Hua C., 1991. Coarse woody debris dynamics in two old-growth ecosystems in Oregon. Bioscience 41: 604-610. DOI: 10.2307/1311697.

Hishinuma T., Osono T., Fukasawa Y., Azuma J.I., Takeda H., 2015. Application of 13C NMR spectroscopy to characterize organic chemical components of decomposing coarse woody debris from different climatic regions. Annals of Forest Research 58(1): 3-13. DOI: 10.15287/afr.2015.356.

Kauffman J.B., Donanto D.C., 2012. Protocols for the measurement, monitoring and reporting of structure, biomass and carbon stocks in mangrove forests. In: Working Paper 86. CIFOR, Bogor, ID, 40 p.

Kebli H., Brais S., Kernaghan G., Drouin P., 2012. Impact of harvesting intensity on wood-inhabiting fungi in boreal aspen forests of Eastern Canada. Forest Ecology and Management 279: 45-54. DOI: 10.1016/j.foreco.2012.05.028.

Kotowska M.M., Leuschner C., Triadiati T., Meriem S., Hertel D., 2015. Quantifying above- and belowground biomass carbon loss with forest conversion in tropical lowlands of Sumatra (Indonesia). Global Change Biology 21: 3620-3634. DOI: $10.1111 /$ gcb.12979.

Laiho R., Prescott C.E., 1999. The contribution of coarse woody debris to carbon, nitrogen, and phosphorus cycles in three Rocky Mountain coniferous forests. Canadian Journal of Forest Research 29: 1592-1603. DOI: 10.1139/x99-132.

Lambers H., Chapin III F.S., Pons T.L., 2008. Role in Ecosystmes and Global Processes. In: Springer (eds). Plant Physiological Ecology, Second Edition. Springer, New York, pp 545-554. 
Liu W., Schaefer D., Qiao L., Liu X., 2013. What controls the variability of wood-decay rates? Forest Ecology and Management 310: 623-631. DOI: 10.1016/j.foreco.2013.09.013.

Lombardi F., Cherubini P., Tognetti R., Cocozza C., Lasserre B., Marchetti M., 2013. Investigating biochemical processes to assess deadwood decay of beech and silver fir in Mediterranean mountain forests. Annals of Forest Science 70: 101-111. DOI 10.1007/s13595012-0230-3.

Mackensen J., Bauhus J., 2003. Density loss and respiration rates in coarse woody debris of Pinus radiata, Eucalyptus regnans and Eucalyptus maculata. Soil Biology and Biochemistry 35: 177-186. DOI: 10.1016/ S0038-0717(02)00255-9.

Margono B.A., Potapov P.V., Turubanova S., Stolle F., Hansen M.C., 2014. Primary forest cover loss in Indonesia over 2000-2012. Nature Climate Change 4: 730735. DOI: $10.1038 /$ nclimate 2277 .

Olajuyigbe S.O., Tobin B., Gardiner P., Nieuwenhuis M., 2011. Stocks and decay dynamics of above- and belowground coarse woody debris in managed Sitka spruce forests in Ireland. Forest Ecology and Management 262: 1109-1118. DOI: 10.1016/j.foreco.2011.06.010.

Palviainen M., Finér L., Laiho R., Shorohova E., Kapitsa E., Vanha-Majamaa I., 2010. Carbon and nitrogen release from decomposing Scots pine, Norway spruce and silver birch stumps. Forest Ecology and Management 259: 390-398. DOI: 10.1016/j.foreco.2009.10.034.

Pan Y., Birdsey R.A., Fang J., et al., 2011. A large and persistent carbon sink in the world's forests. Science 333:988-993. DOI: 10.1126/science.1201609.

Pfeifer M., Lefebvre V., Turner E., Cusack J., Khoo M., Chey V.K., 2015. Deadwood biomass: an underestimated carbon stock in degraded tropical forests? Environmental Research Letters 10: 1-11. DOI: 10.1088/1748-
9326/10/4/044019.

Philpott T.J., Prescott C.E., Chapman W.K., Grayston S.J., 2014. Nitrogen translocation and accumulation by a cord-forming fungus (Hypholoma fasciculare) into simulated woody debris. Forest Ecology and Management 315: 121-128. DOI: 10.1016/j.foreco.2013.12.034.

Pregitzer K.S., Euskirchen E.S., 2004. Carbon cycling and storage in world forests: biome patterns related to forest age. Global Change Biology 10: 2052-2077. DOI: 10.1111/j.1365-2486.2004.00866.x.

Rajala T., Peltoniemi M., Pennanen T., 2012. Fungal community dynamics in relation to substrate quality of decaying Norway spruce (Picea abies [L.] Karst.) logs in boreal forests. Microbiol Ecology 81: 494-505. DOI: 10.1111/j.1574-6941.2012.01376.x.

Strukelj M., Brais S., Quideau S.A., Angers V.A., Kebli H., Drapeau P., Oh S., 2013. Chemical transformations in downed logs and snags of mixed boreal species during decomposition. Canadian Journal of Forest Research 43: 785-798. DOI: 10.1139/cjfr-2013-0086.

Vanholme R., Demedts B., Morreel K., Ralph J., Boerjan W., 2010. Lignin biosynthesis and structure. Plant Physiology 153: 895-905. DOI: 10.1104/pp.110.155119.

[WWF] World Wildlife Fund. 2010. Sumatra's forests, their wildlife and the climate windows in time: 1985 , 1990, 2000 and 2009. WWF Report, Jakarta, ID, 70 p.

Yang F.F., Li Y.L, Zhou G.Y., Wenigmann K.O., Zhang D-Q, Wenigmann M., Liu S-Z, Zhang Q-M., 2010. Dynamics of coarse woody debris and decomposition rates in an old-growth forest in lower tropical China. Forest Ecology and Management 259: 1666-1672. DOI: 10.1016/j.foreco.2010.01.046.

Zhou L., Dai L., Gu H., Zhong L., 2007. Review on the decomposition and influence factors of coarse woody debris in forest ecosystem. Journal of Forestry Research 18: 48-54. DOI: 10.1007/s11676-007-0009-9. 